\title{
JoHN TAYLOR (1597-1655), ENGLISH CATHOLIC GENTLEMAN AND CAROLINE DIPLOMAT
}

\author{
by Thea Lindquist
}

During the Thirty Years' War, John Taylor served at the Habsburg courts in Brussels, Madrid, and Vienna. Although he figured prominently in Charles I's secret Habsburg foreign policy during the war and was one of the "persons of distinction" included in the original Dictionary of National Biography, published information on Taylor is sparse. ${ }^{1}$ His story is especially compelling given his own and his family's connections with Continental Catholicism as well as his involvement, as a gentleman of indisputably Catholic background, in English diplomacy of the time.

John Taylor was born into a gentry family resident at Bickerton Hall in the village of Bickerton, Yorkshire, in 1597. ${ }^{2}$ Bickerton, located in the parish of Bilton in Ainsty, is not far

${ }^{1}$ A. F. Pollard's article on Taylor in the Dictionary of National Biography contains fundamental errors, some of which M. R. Trappes-Lomax noted in the pages of Recusant History; mine on Taylor in The Oxford Dictionary of National Biography rectifies these (Leslie Stephen and Sidney Lee, eds., The Dictionary of National Biography: From the Earliest Times to 1900 [London: Oxford University Press, 1885-1901], vol. 19, 438; H. C. G. Matthew and Brian Harrison, eds., The Oxford Dictionary of National Biography: From the Earliest Times to the Year 2000 [Oxford: Oxford University Press, 2004]; M. R. Trappes-Lomax, 'Who Was John Taylor the Diplomatist?,' RH 7, no. 1 [1963]: 43-5).

${ }^{2}$ Given the popularity of the name John in the Taylor family, it can be difficult to distinguish between them. Figure 1, The Taylor Family, is helpful in differentiating between persons of the same name and understanding relationships among the family members. Also, please note that where "Taylor" stands alone in the text, it always refers to John Taylor the diplomat. Taylor and his uncle of the same name were often referred to as gentleman and at times as esquire. On 12 April 1635, Taylor's uncle received a confirmation of arms to himself as well as to his father and his brothers Stephen (Taylor's father), Thomas, and Robert, and all their descendants (College of Arms, Miscellaneous Grants 7.29; Trappes-Lomax, 45). 


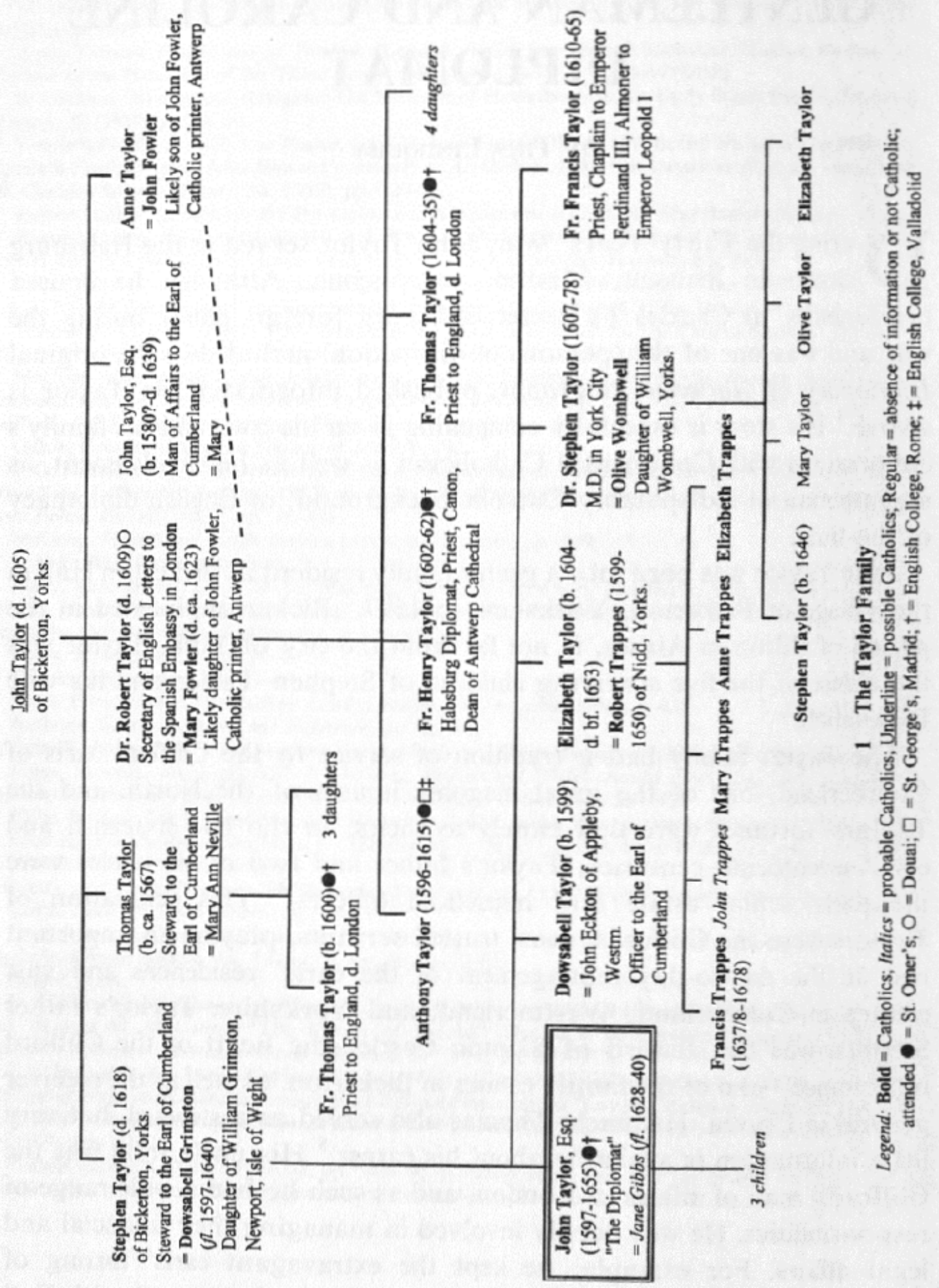


from the city of York. Taylor was the eldest of the five surviving children of Stephen Taylor and his wife Dowsabell. ${ }^{3}$

The Taylor family had a tradition of service to the Clifford earls of Cumberland, one of the great magnate houses of the North, and the Taylors' fortunes were tied closely to theirs. In the late sixteenth and early seventeenth centuries, Taylor's father and two of his uncles were the earls’ senior estate and household officers. ${ }^{4}$ This generation of Taylors were the Cliffords' most trusted servants, playing an important role in the day-to-day management of the earls' residences and vast estates in Cumberland, Westmorland, and Yorkshire. Taylor's father Stephen was the steward of Skipton Castle - the heart of the Clifford inheritance - and of the family estates in Bickerton, as well as the receiver general in Craven. His uncle Thomas also served as a steward, but very little information is available about his career. ${ }^{5}$ His uncle John was the Cliffords' man of affairs in London, and as such he had a wide range of responsibilities. He was deeply involved in managing their financial and legal affairs. For example, he kept the extravagant earls' throng of creditors at bay, negotiated the inheritance dispute between the $4^{\text {th }}$ Earl and his niece, Lady

${ }^{3}$ Dowsabell was the sister of William Grimston, gentleman, the Earl of Cumberland's receiver in Cumberland. The union of Taylor's parents is but one example of the close connections among the Cliffords' officers (Richard T. Spence, 'A Royal Progress in the North: James I at Carlisle Castle and the Feast of Brougham, August 1617,’ Northern History 27 [1991]: 55; idem, The Privateering Earl [Far Thrupp, Stroud, Gloucs.: Sutton, 1995], 38).

${ }^{4}$ Although A. J. Loomie notes Taylor's grandfather was a steward to the 4th Earl, this is impossible as his grandfather died in 1605, before the 4th Earl inherited (Albert J. Loomie, 'Canon Henry Taylor, Spanish

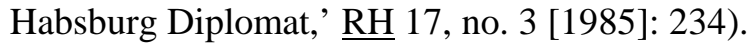

${ }^{5}$ Richard T. Spence, 'The Pacification of the Cumberland Borders, 1593-1628,' Northern History 13 (1977): 141; idem, 'Royal Progress,' 62; Edward Peacock, ed., A List of Roman Catholics in the County of York in 1604 (London: Hotten, 1872), 61; HMC, Salisbury (Cecil), vol. 15, 260: 16 Oct. 1603, Earl of Cumberland to Lord Cecil; ibid., vol. 16, 428: [between 20 Aug. and 5 May 1605], the same to Viscount Cranborne. 
Anne Clifford, and represented the earls' interests in disputes with the Merchant Adventurers over a lucrative cloth license. ${ }^{6}$ It is clear that both John and Stephen Taylor were men of outstanding ability who served their masters well. ${ }^{7}$

Since Taylor's father and uncles worked so closely with the Clifford earls, young Taylor was certainly known to them as well. The Taylors were more than just the Cliffords’ trusted servants. The friendly and casual relationship between Taylor's uncle John, on the one hand, and the $4^{\text {th }}$ Earl and his eldest son, Henry Clifford (Lord Clifford), on the other, is apparent in their correspondence. ${ }^{8}$ Henry Clifford was also on good terms with Stephen Taylor and his family. ${ }^{9}$ Young Taylor's acquaintance with the Clifford earls and the notables who gathered around them very likely opened doors to his future employment in government service.

\section{Religion and Education}

The Clifford earls were unconcerned about consorting with Catholics and maintained friendly relationships with many Catholic relatives and local Catholic gentry families. This was fortunate

${ }^{6}$ CSPD 1603-1610, 402: 7 Feb. 1608, Release for John Taylor and other executors of the late Earl of Cumberland; Richard T. Spence, Lady Anne Clifford: Countess of Pembroke, Dorset and Montgomery (1590-1676) ([Phoenix Mill, Gloucs.]: Sutton, 1997); idem, 'The Cliffords, Earls of Cumberland, 1579-1646: A Study of Their Fortunes Based on Their Household and Estate Accounts,' (Ph.D. diss., University of London, 1959), esp. chap. 10.

${ }^{7}$ Spence, 'Cliffords, Earls of Cumberland,' 367-8.

${ }^{8}$ For example, Thomas D. Whitaker, The History and Antiquities of the Deanery of Craven in the County of York, ed. A. W. Morant, 3d ed. (Leeds: Dodgson, 1878), 361-2: June 1611, Taylor to Clifford; Spence, 'Cliffords, Earls of Cumberland'; M. R. Trappes-Lomax, 45. This uncle also accompanied Clifford as an esquire on the occasion of his being made a Knight of the Bath in June 1610.

${ }^{9} \mathrm{He}$ stood as godfather, for instance, to Stephen Taylor's eldest daughter, Dowsabell, who later became one of gentlewomen of Countess Grissell, Clifford's mother (BIHR, Parish Registers, Bilton in Ainsty, County York). 
for the Taylors, as most of them were Catholics of some sort, ranging from church papists to full-fledged recusants. The Cliffords often stayed in Bickerton, and the Taylors' religious preference was not an issue for them. ${ }^{10}$

The Cliffords' casual attitude was partly due to the fact that Catholicism and even recusancy was not unusual among the Yorkshire gentry at the time. Even though Catholics made up a comparatively small proportion of the overall population, Catholicism was more prevalent among the gentry. J. C. H. Aveling estimates that gentry households accounted for approximately two-thirds of Yorkshire Catholics in the latter half of Elizabeth's reign. He notes that the old faith was particularly strong among the gentry of the West Riding, including the Ainsty: "The community of hereditary Catholics in the West Riding counted as one of the largest, most productive of martyrs and vocations, and wealthiest in England." ${ }^{11}$ According to Aveling, approximately one-quarter of the nobility and landed gentry there was Catholic until the end of the seventeenth century. ${ }^{12}$

While recusancy was fairly common among the Yorkshire gentry, it should be noted that few families were purely recusant. The head of the family often resorted to occasional conformity to protect his property and avoid fines and imprisonment. Children raised in recusant households

\footnotetext{
${ }^{10}$ Spence, Privateering Earl, 37-8.

${ }^{11}$ J. C. H. Aveling, 'The Catholic Recusants of the West Riding of Yorkshire, 1558-1790,' Proceedings of the Leeds Philosophical and Literary Society, Literary and Historical Section 10, no. 6 (1963): 191.

${ }^{12}$ Aveling, ‘Catholic Recusants,' 191; idem, ‘Catholic Households in Yorkshire, 1580-1603,' Northern History 16 (1980): 85. On the Catholic gentry in Yorkshire, see J. T. Cliffe, The Yorkshire Gentry: From the Reformation to the Civil War, University of London Historical Studies, vol. 25 (London: Athlone Press, 1969), chaps. 8-10.
} 
also did not always remain Catholic, and most landed Catholic families in Yorkshire had "schismatic" branches. ${ }^{13}$ These developments were hardly surprising given the penal laws against Catholics on the books at the time, even if they were not strictly enforced. Still, there was a significant group of recusants among the Yorkshire elite, whose influence reached far beyond their numbers, especially in certain localities. Taylor’s family was among them.

Just as Stephen Taylor's Catholicism did not prejudice his relationship with the Cliffords, it did not derogate his family's status in Bickerton and the parish of Bilton. On the contrary, the Taylors were associated with one of the great English noble families, and, like most local gentry, they were respected and well-established members of the community. ${ }^{14}$ The influence of the Catholic gentry on recusancy among the lower classes in their communities is well documented. William Sheils has shown that consideration of the distribution of gentry Catholicism is necessary to a proper understanding of peasant recusancy in the West Riding. ${ }^{15}$ This was even more the case, he argues, in the Ainsty:

\footnotetext{
${ }^{13}$ Alexandra Walsham, Church Papists: Catholicism, Conformity and Confessional Polemic in Early Modern England (Woodbridge, Suffolk: Boydell, 1993), 76-80; Cliffe, 227; J. C. H. Aveling, 'Some Aspects of Yorkshire Recusant History,' in The Province of York, ed. G. J. Cuming, Studies in Church History, vol. 4 (Leiden: Brill, 1967), 110.

${ }^{14}$ The inhabitants of the parish of Bilton honored Dowsabell by asking her to stand as godmother to two children, and eleven more shared her unusual name; and these are limited to those children baptized in the established church. In the parochial context, this was a mark of respect for a known recusant lady (BIHR, Parish Registers, Bilton in Ainsty, County York).

${ }^{15}$ William J. Sheils, 'Household, Age and Gender among Jacobean Yorkshire Recusants,' in Marie B. Rowlands, ed., English Catholics of Parish and Town, 1558-1778, CRS Publications, Monograph Series, vol. 5 (London: CRS, 1999), 148; A. G. Dickens, 'The Extent and Character of Recusancy in Yorkshire, 1604,’ Yorkshire Archaeological Journal 37 (1942): 40.
} 
[R]ecusants of below gentry status cannot be considered independently of their social superiors. All of the clusterings [of recusants] ... existed in close proximity to gentry presence, and, in the case of the parishes in the Ainsty they owed their presence very directly to the gentry, mostly being employed in their households or as tenants on their farms. ${ }^{16}$

The Taylors' presence, therefore, provided important support to the enclave of Catholics in Bickerton and the parish of Bilton, which included their servants, tenants, and other parishioners. In 1604, for instance, two of John Taylor's servants were presented along with their master for noncommunicancy at Easter. ${ }^{17}$ Stephen Taylor was cited in 1615 for neglecting to send his children and his servants to be catechized. Moreover, several inhabitants of the parish were reported for non-attendance at church and other conservative practices. ${ }^{18}$

During a time when persecution was driving many Catholics to conform, Taylor's parents were devoted to the old faith. Unlike some Catholic men of his class, Stephen Taylor did not leave the spiritual leadership of the household to his wife to avoid the penalties of recusancy. Instead he ran the risk of heavy fines and loss of property by refusing to conform. Both of Taylor's parents heard mass when they could and refused to attend parish services on Sundays and days of obligation as required by law. These transgressions did not escape the notice of the authorities. The Bishop of London complained to the Earl of Salisbury in 1606 that Stephen Taylor and one of his sons not only lodged but also attended mass at the Spanish ambassador's

\footnotetext{
${ }^{16}$ Sheils, 134.

${ }^{17}$ Peacock, 61. This was in all likelihood Taylor's grandfather or possibly his uncle.

18BIHR, AVCB 1615, ff. 31-2; BIHR, AVCB 1619, f. 24.
} 
house. ${ }^{19}$ Also, the Yorkshire ecclesiastical courts repeatedly called Stephen and Dowsabell to answer charges of recusancy and noncommunicancy, though it seems they never heeded these summons. Recusants frequently employed this tactic to evade prosecution. ${ }^{20}$ As previously mentioned, Stephen was presented for neglecting to send his servants and children to be catechized, and in 1619, shortly after his death, Dowsabell was expelled from the established church for "standing excommunicate for seven years or thereabouts."21 After Thomas Wentworth (later Earl of Strafford) took control of the Northern Commission for Compounding with Recusants in 1629, he used the anti-Catholic laws to increase Charles I's revenues by encouraging determined recusants like Dowsabell to make financial composition as a way to avoid future harassment and prosecution. ${ }^{22}$ In 1632, after she had relocated to the neighboring parish of Tadcaster, she paid £2 in composition fees to the Northern Commission.

Still, things could have been worse for the Taylors. Since there was often community pressure to hide the recusancy of individuals of standing, they may have been able to avoid more frequent prosecution than they otherwise encountered. In addition, their residence in a peculiar

${ }^{19} \mathrm{HMC}$, Salisbury (Cecil), vol. 18, 23: 17 Jan. 1606, Bishop of London to Salisbury.

${ }^{20}$ BIHR, AVCB 1604, f. 26; BIHR, AVCB 1615, f. 32; BIHR, AVCB 1619, ff. 23-4; BIHR, AVCB 1623, f. 20; BIHR, AVCB 1627, f. 31; Peacock, 61; Aveling, 'Catholic Recusants,' 285. For a list of recusants in the West Riding of Yorkshire to 1780, arranged by parish, see J. C. H. Aveling's "Catholic Recusants," app. I.

${ }^{21}$ BIHR, AVCB 1619, f. 24.

${ }^{22}$ In order to secure recusant compositions as a long-term source of revenue for the Crown, Wentworth preferred to ask for manageable sums instead of imposing heavy penalties that would severely impair recusants' ability to make future contributions. For more on Wentworth and his policies toward recusants

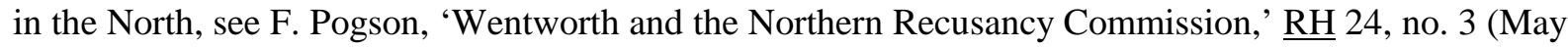
1999): 271-87. 
jurisdiction - a parish or area exempt from the jurisdiction of archdeacons and rural deacons and subject to that of another individual or body - could only help their situation. Bilton in Ainsty was subject to the jurisdiction of the prebendaries of York Minster, and as such local officers were less likely to scrutinize its parishioners closely.

The Catholicism of Taylor's parents made a deep impression not only on him, which is discussed below, but also on his siblings, as evidence indicates most of them remained staunch Catholics throughout their lives. His youngest brother, Francis, received his religious training at St. Gregory's College, Seville, and became a priest. He went on mission to England in the summer of 1638 but was apprehended upon his arrival. ${ }^{23}$ By 1641, he had entered the service of the Emperor Ferdinand III as a court chaplain and eventually rose to become Leopold I's almoner. ${ }^{24}$ Taylor's other brother, Stephen, became a well-known recusant medical doctor in York. ${ }^{25}$ Over the years, Stephen and his family were repeatedly presented for recusancy. During the Interregnum, the York Committee for Compounding sequestered the property of well-off Catholics in the city, only four of whom it found worthy of its attention. Stephen Taylor was among them, but he somehow managed to elude the fines it imposed on him. ${ }^{26}$ The elder of

\footnotetext{
${ }^{23}$ Martin Murphy, St. Gregory's College, Seville, 1592-1767, CRS Publications, Records Series, vol. 73 (London: CRS, 1992), 98.

${ }^{24} \mathrm{By}$ this time Taylor was already well-known to the Imperial court, where he had served as Charles I's resident agent from 1635 to 1639.

${ }^{25}$ Dr. Stephen Taylor set up his practice in 1627 in St. Martin's, Coney Street. He was born in 1607 rather than earlier, as A. J. Loomie surmises (BIHR, Parish Registers, Bilton in Ainsty, County York; Loomie, 'Henry Taylor,' 235).

${ }^{26}$ J. C. H. Aveling, Catholic Recusancy in the City of York, 1558-1791 (London: CRS, 1970), 85, 89, 240, 242 n. 15, 243, 248; Calendar of the Proceedings of the Committee for Compounding \& C., 1643-1660 (London: HMSO, 1889-92; reprint, Nendeln, Liech.: Kraus Reprint, 1967), vol. 3, 113: 23 Apr. 1648,
} 
Taylor's two younger sisters, Dowsabell, was also committed to the old faith. Although the religious sympathies of his other sister, Elizabeth, may have wavered in her youth, she was a Catholic and recusant during her adult life. ${ }^{27}$

Beyond his nuclear family, Taylor's extended family also showed a strong proclivity to Catholicism. The number of family members who were priests and/or held prominent positions in the Catholic community in England and abroad is overwhelming. Taylor's uncle, Robert Taylor, chose exile in Flanders rather than persecution for his faith, leaving England for the Continent early in Elizabeth's reign. His wife Mary was very likely the daughter of John Fowler, eminent printer of early recusant literature. ${ }^{28}$ Robert became a professor of civil law at Douai and later served as secretary of English letters to the Spanish ambassadors in England, from 1603 until his death in 1609. As secretary, he participated in the most sensitive Anglo-Spanish

Rob. Horner, mayor, and the Committee for the City and County of York to the Committee for Compounding. For a list of recusants in York similar to that for the West Riding, see Aveling, 'Catholic Recusancy,' app. I.

${ }^{27}$ Elizabeth was the sister that Taylor designated as a non-Catholic in his statement upon entering the English College in Rome (cf. p. 15). An Elizabeth Taylor, however, was cited for recusancy in the parish of Bilton in 1623 and 1627 (BIHR, AVCB 1623, f. 20; BIHR, AVCB 1627, f. 31). By 1633, Elizabeth had married Robert Trappes of Nidd, a recusant from a well-known Yorkshire Catholic family and Wentworth's first cousin. In 1633, recusancy processes were underway against both Robert and Elizabeth Trappes. At the request of Robert's father Francis, Wentworth in fact approached the King on their behalf and received permission to compound father and son for recusancy at $£ 8$ per year. During the Commonwealth, Robert's lands were sequestered for actively supporting the King against Parliament (John Trappes-Lomax, ed., 'Trappes of Nidd: A Family History by Richard Trappes-Lomax,' RH 27, no. 2 [Oct. 2004], 163-7, 175-6; William Dugdale, The Visitation of the County of Yorke, begun in...1665 and finished in...1666, Surtees Society Publications, no. 36 [Durham: Surtees Society, 1859], 214; Bill Williams, Bilton through the Ages [York: Published by the Author, 1985]). For further information on the Trappes and their descendants, see John Trappes Lomax, 'Trappes of Nidd.'

${ }^{28}$ Albert J. Loomie, ‘Francis Fowler II, English Secretary of the Spanish Embassy, 1609-1619,’ RH 12 (1973): 70. 
negotiations of the day. ${ }^{29}$ While in England in this capacity, he was intimately involved in Catholic affairs. He sheltered priests, including Father John Gerard in the aftermath of the Gunpowder Plot in 1605. ${ }^{30}$ Although Robert Taylor associated with the plotters, there is no evidence that he actually helped plan the attack. ${ }^{31}$ As a Spanish diplomatic official, Robert also played a part in the trial of the Jesuit superior Henry Garnet in $1606 .{ }^{32}$ After the priest’s execution, he procured Garnet's ear - a relic Catholics believed bore the image of the executed priest’s face - for the Spanish ambassador Don Baltazar de Zúñiga. ${ }^{33}$ Additionally, Robert Taylor's sister Anne, Taylor's only paternal aunt, married John Fowler, brother of Mary (Fowler) Taylor and Francis Fowler, who succeeded Robert as secretary of English letters for the Spanish

\footnotetext{
${ }^{29}$ For more on Dr. Robert Taylor, see Albert J. Loomie, ‘Sir Robert Cecil’; idem, The Spanish Elizabethans: The English Exiles at the Court of Philip II (New York: Fordham University Press, 1963); idem, 'Toleration and Diplomacy: The Religious Issue in Anglo-Spanish Relations, 1603-1605,' Transactions of the American Philosophical Society, n.s. 53, pt. 6 (1963); idem, ed., Spain and the Jacobean Catholics, CRS Publications, vol. 64 ([London]: CRS, 1973), vol. 1; and L. Hicks, 'The Embassy of Sir Anthony Standen in 1603: Part I,' RH 5 (1959-60): 91-127.

${ }^{30} \mathrm{~A}$ few months later, Robert Taylor's house was raided and the Taylors were imprisoned for hiding yet another priest (Michael Hodgetts, ‘A Topographical Index of Hiding Places,' RH 16, no. 2 [1982]: 176).

${ }^{31}$ According to notes of meetings related to the "gunpowder treason," Robert Taylor attended the Thursday "sennett" that gathered for dinner at the Mitre tavern in Broad Street in the days before 5 November 1605; plotter Robert Catesby was also present (HMC, Salisbury (Cecil), vol. 17, 522: [Nov. 1605], Gunpowder Plot; Alan Haynes, The Gunpowder Plot: Faith in Rebellion [Phoenix Mill, Gloucs.: Sutton, 1994], 74).

${ }^{32}$ Loomie, ‘Sir Robert Cecil,’ 36.

${ }^{33}$ Henry Foley, ed., Records of the English Province of the Society of Jesus: Historic Facts Illustrative of the Labours and Sufferings of Its Members in the Sixteenth and Seventeenth Centuries (London: Burns and Oats, 1875-83; reprint, New York: Johnson Reprint, [1966]), vol. 4, 127-8. For the story of Garnet's ear, with contemporary accounts and illustrations of the ear, see Foley, 120-34, and Philip Caraman, Henry Garnet, 1555-1606, and the Gunpowder Plot (New York: Farrar, Straus, 1964), app. D.
} 
embassy. Anne (Taylor) Fowler was a well-known Catholic bookseller who plied her trade out of her home near the Inns of Court. ${ }^{34}$

Several of Taylor's first cousins went on to careers in the Church. All three of Robert Taylor's sons had a religious vocation: Anthony, who studied at St. Omers and the English colleges in Madrid and Valladolid, died before he could realize his goal of becoming a priest; Thomas, who studied at St. Omers and the English College at Rome, was ordained in 1628 and died while doing missionary work in England; and the most illustrious, Henry, who was educated at St. Omers and the English College at Rome, became a resident agent for the Spanish Habsburgs in London, court chaplain in Brussels, and Dean of Antwerp Cathedral. He was even considered for a titular bishopric. Additionally, Taylor's cousin Thomas, son of his uncle Thomas Taylor, though raised a Protestant, converted to Catholicism and became a priest. Young Thomas's uncle Robert Taylor brought him to Flanders, where he attended St. Omers. Afterward he studied at the English College at Rome and eventually returned to England as a priest. ${ }^{35}$ Finally, many of the Taylors of Tadcaster, which is located only a few miles from Bickerton, were also recusants, and they were very likely cousins of the Taylors of Bickerton Hall. ${ }^{36}$ When

\footnotetext{
${ }^{34}$ Loomie, 'Fowler,' 75.

${ }^{35}$ Kenny, vol. 1, 326; Foley, vol. 6, 290, 510; Geoffrey Holt, St. Omers and Bruges College, 1593-1773: A Biographical Dictionary, CRS Publications, Records Series, vol. 69 ([London]: CRS, 1979), 258. Although young Thomas records in his statement upon entering the English College that his parents and three sisters are heretics, his parents did not consistently conform, since "Thomas Taylor gentleman, steward to the Earl of Cumberland...and his wife” were reported for recusancy in the parish of Bilton (Peacock, 61).

${ }^{36}$ BIHR, AVCB, for instance 1636, ff. 44-5, and Cause Papers, H 463; Aveling, 'Catholic Recusants,' app. I. The Taylors of Tadcaster were postmasters there since the late 1570s (BL, Add. Mss. 28566, n.f.: "Iter Boreale, Anno Salutis 1639": John Aston's Diary; CSPD 1637, 331: 27 July 1637, Warrant to pay for posts).
} 
one surveys the religious leanings of the Taylor family through two generations, the unmistakable picture of a predominantly Catholic family emerges. ${ }^{37}$

Given the strength of his family's religious conviction, it comes as no surprise that Taylor's parents ensured that he was brought up and educated in the Catholic faith. He likely learned the fundamentals from either his parents or a private tutor, or perhaps in one of the clandestine Catholic schools that were quite widespread in the North of England in the early seventeenth century. ${ }^{38}$ In 1612, his parents enrolled him for further education in the Jesuit-run St. Omers College in Flanders, the leading English Catholic school on the Continent, where he studied for the next seven years. ${ }^{39}$ St. Omers was a place for English Catholic boys to perfect their learning, not only preparing them for the seminaries but also providing a quality Catholic education in the classical humanities to lay students like Taylor. Lay students made up a large majority of the student body, numbering roughly four to every one vocation. ${ }^{40}$

Sending an heir abroad for an education meant risks and sacrifices for all involved. While at St. Omers, Taylor adopted the alias John Grimston to avoid government detection, which could result in heavy penalties for himself and his parents. ${ }^{41}$ Such an education was also

\footnotetext{
${ }^{37}$ See Figure 1.

${ }^{38}$ A. C. F. Beales, Education under Penalty: English Catholic Education from the Reformation to the Fall of James II, 1547-1689 ([London]: Athlone Press, 1963), ix, 56-7, 74-5, 81, 83; Cliffe, 194-5.

${ }^{39}$ Holt, 258.

${ }^{40}$ Beales, 70, 169.

${ }^{41}$ Parents who sent their children to Continental seminaries were liable to forfeit their lands and goods, and the same punishment applied to children who refused to conform.
} 
expensive - fees amounted to at least $£ 25$ a year and had to be paid six months in advance. ${ }^{42}$ The fact that the Taylors were willing to pay such a sum and risk persecution in order for their eldest son to receive a Catholic education underlines their strong religious commitment.

Unfortunately for Taylor, his father Stephen passed away in 1618, toward the end of his stay at St. Omers. With his clearly Catholic eldest son abroad and his two younger sons still minors in the care of a recusant mother, Stephen's inheritance passed to his brother, Taylor's uncle John, who seems to have incurred no religious infractions. ${ }^{43}$ The hope apparently was that Taylor's uncle would either eventually transfer ownership of the estate to Taylor or one of his brothers when feasible or leave it to them upon his death. After her son's disinheritance, Taylor's mother did not remain in Bickerton but instead moved to Tadcaster. There are several reasons she may have relocated, perhaps to distance herself from her “conformist” brother-in-law John, who took over at Bickerton Hall, to escape the scrutiny of Thomas Stockdale, a fervent Puritan who had purchased a nearby estate, or to seek the support of sympathetic relatives. ${ }^{44}$ It seems, therefore, that Stephen Taylor's family may have finally paid the price for its recusancy in the disinheritance of Taylor and his brothers and their mother’s “exile” to Tadcaster.

The loss of his inheritance may have been a factor in Taylor's decision to consider the priesthood. In 1619, after finishing his studies at St. Omers, he was admitted as a convictor to the

\footnotetext{
${ }^{42}$ Beales, 53, 160.

${ }^{43}$ Uncle John's religious proclivities are unclear, but if he was a Catholic, he had taken care to stay out of trouble with the authorities.

${ }^{44}$ John Trappes-Lomax, 167. A recusant widow could lose two-thirds of her dower or jointure and all claim to her husband's goods.
} 
English College in Rome. The English College was the epicenter of English Catholicism on the Continent. ${ }^{45}$ Each scholar entering the English College was asked to respond to questions about his family, upbringing, health, and education, known as the Responsa Scholarum. In his statement, Taylor affirmed that his entire family was Catholic except for his younger sister, Elizabeth. ${ }^{46}$ In the late spring of 1621, however, after less than two years in Rome, Taylor decided to forgo a religious career. Even so, his Catholic upbringing and education helped to ensure that he remained a steadfast Catholic throughout his life. ${ }^{47}$

Little is known of Taylor's activities during the ensuing seven years, but at some point, he returned to England. It may be during this period that he married Jane Gibbs, with whom he had three children by $1639 .{ }^{48}$ Unable to claim his inheritance and having given up a life in the Church, Taylor's options were limited.

\footnotetext{
${ }^{45}$ Beales, 121. Kenny, pt. 1, 327. Although the English College was a seminary for training priests, it sometimes took St. Omers students who were unsure of their vocation, like Taylor (Beales, 130).

${ }^{46}$ Anthony Kenny, ed., The Responsa Scholarum of the English College, Rome, pt. 1, 1598-1621, CRS Publications, Records Series, vol. 54 ([London]: CRS, 1962), 327.

${ }^{47}$ Thus the great S. R. Gardiner's statement, accepted at face value by many succeeding historians, that Taylor was a Catholic and half a Spaniard by birth was only half true (Samuel R. Gardiner, History of England from the Accession of James I. to the Outbreak of the Civil War, 1603-1642 [London: Longmans, Green, 1884], vol. 8, 101). Gardiner may have been misled by a letter in which Edward Hyde, Earl of Clarendon, sarcastically wrote that Taylor bore the delays of the Imperial Diet "like a man bred in the Court of Spain." (CCSP, vol. 2, 327: 27 Mar. 1654, Hyde to Bellings).

${ }^{48}$ PRO, SP 16/433, f. 102: 25 Nov. 1639, Taylor to Windebank; PRO, SP 16/470, f. 164: [Oct?] 1640, Jane Taylor's petition to Charles I.
} 


\section{Career}

Taylor settled upon a career in government service, probably in the hope of sufficiently distinguishing himself in the King's eyes to reclaim his legacy. He had secured his first government employment by 1628 and found his niche two years later, when he began his long career as an English diplomat at the Habsburg courts in Vienna, Brussels, and Madrid. ${ }^{49}$ Taylor had a couple of advantages in pursuing this type of work. First, he had connections with the court through the Earl of Cumberland and his friends. Taylor would have been well known not only to the Cliffords but also to Wentworth, the diplomat Sir Edward Wotton, and other notables who journeyed with them, all of whom were in the position to help him to a government post. ${ }^{50}$ Also, Taylor had spent time on the Continent and had shown an aptitude for languages, a desirable if not required ability in a seventeenth-century diplomat.

Since England at this time was widely regarded as the leading Protestant power in Europe, it is relevant to ask why Charles I employed a Catholic gentleman of a known recusant family as his diplomat to the Habsburg courts. Actually, from the King’s perspective, Taylor’s faith made him an ideal candidate for the job. It not only rendered him palatable to the Habsburgs but also a vulnerable and loyal servant to the King. Taylor, like many English Catholic

\footnotetext{
${ }^{49}$ PRO, SP 16/189, f. 145: 29 May 1635, "The Account of John Taylor sent into Spain for his Majesty’s affairs, 13 July 1634"; Bodl. Lib., Clar. Mss. 14, f. 113: 5 July 1638, Taylor to Windebank; Bodl. Lib., Clar. Mss. 14, ff. 119-21: 11 July 1638, same to same; PRO, SP 16/433, f. 102: 25 Nov. 1639, same to same.

${ }^{50}$ Wentworth and Taylor were well acquainted in 1633, when Taylor was assisting him with a scheme to promote trade between Ireland and Spain (David Masson, The Life of John Milton: Narrated in Connection with the Political, Ecclesiastical and Literary History of His Time, new and rev. ed. [New York: P. Smith, 1946], vol. 1, 695). That same year, Wentworth assisted Taylor's brother-in-law Robert Trappes and his father Francis Trappes compound for their recusancy on favorable terms (c.f. n. 27).
} 
gentlemen, was eager to show his loyalty to the Crown, and his financial insecurities as a Catholic made him completely reliant upon the King for his livelihood. ${ }^{51}$ Most importantly, due to the King's concerted policy of secrecy in the Habsburg negotiations and to Protestant hostility against Taylor as a papist and Habsburg sympathizer, Charles and his advisors could easily denounce his actions if his negotiations were exposed, without implicating themselves. Thus, because of Taylor's devotion to the Crown and insecure financial and religious status, the King could use his services to carry out an unpopular foreign policy and disavow him at will. Under these circumstances, it comes as no surprise that Charles employed Taylor as a diplomat and that the latter became a key instrument in his secret Habsburg foreign policy.

The main foreign policy issues confronting Charles I's government in the 1630s revolved around England's potential role in the Thirty Years' War and more particularly around the Palatinate question - if, when, and how much of the Palatine lands and dignities would be restored to its deprived elector. The Palatinate question was one of the most vexing issues of the war, and its resolution was necessary to achieve lasting peace in the Empire. ${ }^{52}$ The problem had its genesis in the Calvinist Elector Palatine Frederick V’s acceptance of the Bohemian crown from Protestant rebels in 1619, an act that ultimately lost him his newly acquired kingdom and

\footnotetext{
${ }^{51}$ Many moderate Catholics who wished to show their loyalty took the Oath of Allegiance, and the King preferred to tax and tolerate them rather than attempt to force their conversion. He even allowed them to serve in his foreign service and at the highest levels of government. For a recent summary of historiography relating to Catholics and the Oath and a reassessment of its intent and impact, see Michael C. Questier, 'Loyalty, Religion and State Power in Early Modern England: English Romanism and the Jacobean Oath of Allegiance,’ Historical Journal 40, no. 2 (1997): 311-29.

${ }^{52}$ Dieter Albrecht, 'Bayern und die pfälzische Frage auf dem Westfälischen Friedenskongreß,' in Der Westfälische Friede, ed. Heinz Duchhardt, 461-8, Historische Zeitschrift, suppl. vol. 26 (Munich: Oldenbourg, 1998), 462-3.
} 
his ancestral lands and titles. These events might not have attracted undue attention in England, but Frederick was married to Elizabeth Stuart, James I's daughter and Charles I’s sister. As matters stood, English dynastic interests and the Protestant cause in the Empire had suffered a crushing blow.

Although from a dynastic perspective the English kings were concerned with supporting Frederick's claims, they avoided making his affairs the grounds for English military intervention in the war. ${ }^{53}$ Instead they turned to diplomacy as the main avenue to address the Palatinate question. English attempts to reach a reasonable compromise with the powers which now held a stake in the Palatinate - the Emperor, Spain, and Bavaria - were complicated, however, by the violent opposition of both Frederick and Elizabeth, who would not be satisfied with anything less than the full restoration of the Palatine lands and dignities. ${ }^{54}$ They believed that force was the only means to regain their right permanently, and after the death of her husband in 1632, Elizabeth continued to favor this strategy for the restoration of their son, Charles Louis, and cultivated as much support as she could among the Protestant element in England. ${ }^{55}$

The country was seriously divided on the issue of the Palatinate and English foreign policy, as was the court, where the debate became associated with the rivalry of factions and the

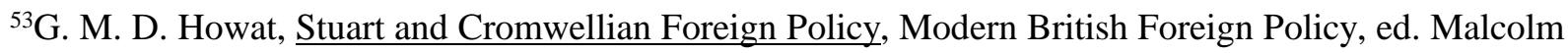
Robinson (London: Adam \& Charles Black, 1974), 2.

${ }^{54}$ Francis C. Springell, Connoisseur \& Diplomat: The Earl of Arundel's Embassy to Germany in 1636 as Recounted in William Crowne's Diary, the Earl's Letters and Other Contemporary Sources with a Catalogue of the Topographical Drawings Made on the Journey by Wenceslaus Hollar (London: Maggs Bros., 1963), 1.

${ }^{55}$ See, for instance, Elizabeth, Queen of Bohemia, The Letters of Elizabeth, Queen of Bohemia, ed. L. M. Baker, with an introduction by C. V. Wedgwood (London: The Bodley Head, 1953), 92-4: 1 June 1636, 
religious sympathies of their adherents. Many of the kings' Protestant subject believed England should intervene in Germany to support the Palatines as Frederick and Elizabeth advised, thus striking a blow for the Protestant cause. Others, both Protestant and Catholic, promoted the same course of action but in alliance with Catholic France. At court these men constituted the war party, or the group that supported English intervention on the anti-Habsburg side (Sweden, the Dutch Republic, France, or a combination thereof). Their opponents, on the other hand, saw the wisdom of negotiating with the Habsburgs, whom they believed were in the best position to restore the Prince Palatine's lands and dignities. They formed the peace party at court and tended to include those with Catholic sympathies. ${ }^{56}$

While for many of his subjects these foreign policy issues were highly charged with religious significance, for Charles I, who assumed the throne in 1625, they were largely dynastic. Although he negotiated with any power that might help him regain the Palatinate, Charles chose to focus on secret negotiations with the Habsburgs through his closest peace party ministers Lord Treasurer Weston, Secretary Windebank, and Sir Francis Cottington - and a stable of diplomats, most with Catholic connections. To avoid criticism of this policy, they concealed the true nature of the negotiations from most courtiers, diplomats, and privy councillors, most particularly those associated with the war party. Already under fire for his high church

Elizabeth to Archbishop Laud.

${ }^{56}$ Albert J. Loomie, 'The Spanish Faction at the Court of Charles I, 1630-8,' Bulletin of the Institute of Historical Research 59 (May 1986): 48; Simon Adams, 'Spain or the Netherlands?: The Dilemmas of Early Stuart Foreign Policy,' in Before the English Civil War: Essays on Early Stuart Politics and Government, ed. Howard Tomlinson (London: Macmillan, 1983), 87, 90. The peace party supported a policy of pro-Habsburg neutrality rather than active intervention on the Habsburg side. 
innovations, Catholic queen, and perceived preferential treatment of Catholics at court, Charles did not wish to make matters worse by revealing his dealings with the Catholic Habsburgs. In his negotiations with foreign governments during the Thirty Years' War, Taylor faithfully served the interests of the peace party. He was convinced that the best route to the restoration of the Palatinate was via Vienna and Madrid, and throughout most of his diplomatic career, he remained a strong proponent of a pro-Habsburg foreign policy. Taylor so ardently wished that Charles and the Habsburgs could reach some sort of accommodation on the Palatinate question that he was often willing to minimize the obstacles and exaggerate the likelihood of an agreement in his dispatches home. Since Taylor corresponded primarily with Weston (until his death in 1635), Cottington, and Windebank, knowledge of his activities was often limited to these men and the King.

Taylor first surfaced in the King’s service at Habsburg courts in April 1630, when he was on assignment gathering news for Weston in Brussels. ${ }^{57}$ Soon thereafter, he was posted to the Empire to keep Weston and the peace party informed about the goings-on at the electoral meeting at Regensburg and then at the Imperial court in Vienna. ${ }^{58}$ Although his efforts inconvenienced those of Sir Robert Anstruther, the accredited English ambassador to the Emperor and Imperial Diet and client of the war party, Taylor secretly met with Imperial and

\footnotetext{
${ }^{57}$ PRO, SP 77/19, f. 335: 18 Apr. 1630, Taylor to [Weston].

${ }^{58}$ His correspondence, mostly directed to Weston, is in PRO, SP 80/7-8 and HMC, Denbigh, vol. 5 (London: HMSO, 1911). Taylor acted as Weston's agent in Imperial political circles but not as a Spanish agent in England as L. J. Reeve suggests (L. J. Reeve, 'Quiroga's Paper of 1631: A Missing Link in Anglo-Spanish Diplomacy during the Thirty Years' War,’ English Historical Review 101 [1986]: 921).
} 
Spanish ministers to promote the peaceful settlement of the Palatinate question. ${ }^{59}$ Given the competing messages this sent to the Habsburgs, it comes as no surprise that Taylor departed from Vienna in August 1632 without having reached an agreement with them. ${ }^{60}$ He returned to Brussels in October and resumed his news-gathering activities there for a time before returning to England, where in the summer of 1633 he aided Wentworth in a scheme to promote trade between Ireland and Spain. ${ }^{61}$ At this time both Wentworth and Taylor were in contact with the Spanish resident agent in London, Juan Necolalde, to whom Wentworth looked to support this business. $^{62}$

Taylor quickly became more involved in Anglo-Spanish affairs. From July 1634 to May 1635, he was sent to Madrid as an accredited diplomatic agent to expedite the negotiations for a secret Anglo-Spanish maritime treaty that was already underway in England. ${ }^{63}$ Initially, Taylor's charge was to secure the recall of Necolalde, whom the English peace party ministers blamed for the slow progress of the treaty negotiations. Taylor accomplished his task with dispatch, for by

${ }^{59} \mathrm{PRO}, \mathrm{SP}$ 80/7, f. 220: [1630?], Taylor to [Weston]; PRO, SP 80/8, f. 86: 21 Oct. 1631, Anstruther to [Weston?].

${ }^{60}$ PRO, SP 80/8, f. 217: 20 Aug. 1632, Abstract of a letter from Taylor to Weston.

${ }^{61}$ PRO, SP 77/22. Taylor remained in Brussels until at least December (PRO SP 77/22, f. 306: 7 Dec. 1632, Taylor to [Weston]).

${ }^{62}$ Thomas Wentworth, Earl of Strafford, The Earl of Strafforde's Letters and Dispatches, ed. William Knowler (London: Printed for the Editor, 1739), vol. 1, 95-6: 1 Aug. 1633, Taylor to Wentworth; Strafford, vol. 1, 104: 22 Aug. 1633, same to same.

${ }^{63}$ Taylor's correspondence while in Spain is in PRO, SP 94/37 and CSP, vol. 1. He arrived in Madrid on 5 August 1634 (PRO, SP 94/37, f. 97: 14 Aug. 1634, Taylor to Portland). 
August, Philip IV had nominated the Count of Humanes as Necolalde's replacement. ${ }^{64}$ Once he achieved this objective, Taylor was ordered to remain in Spain until news of the conclusion of the treaty came from England. During this time he had several discussions with Philip’s most trusted minister, the Count-Duke of Olivares, about important issues, including the Palatinate. ${ }^{65}$ Olivares was favorably inclined toward Taylor, though this may have stemmed more from the latter's pro-Habsburg stance than his skill in negotiation. ${ }^{66}$ Still, in the estimation of Sir Arthur Hopton, the English resident agent in Spain, Taylor was "a very honest and careful man" who acquitted his diplomatic duties in Spain quite satisfactorily. ${ }^{67}$

Soon after his return to England, Taylor secured an important post as resident agent to the Imperial court in Vienna, where he served from November 1635 until early $1639 .{ }^{68}$ This mission was the most important of his career, as he was entrusted with the primary negotiations with Emperor Ferdinand II on the Palatinate question. Taylor's negotiations with the Emperor began auspiciously - soon after his arrival in Vienna, the Emperor agreed to the partial restoration of the Palatinate and hinted that full restitution would be possible in the future. Elated, Taylor

${ }^{64}$ CSP, vol. 1, 126: 22 Aug. 1634, Hopton to Windebank; CSPV 1632-36, 291: 27 Oct. 1634, Anzolo Correr, Venetian Ambassador in England, to the Doge and Senate. Humanes's departure was repeatedly delayed, so long in fact that he died before he could leave for England (CSP, vol. 1, 329: 29 Sept. 1635, Hopton to Windebank; CSPV 1632-6, 471: 2 Nov. 1635, Correr to the Doge and Senate).

${ }^{65}$ PRO, SP 94/37, f. 128: 18 Oct. 1634, Taylor to Olivares; PRO, SP 94/37, f. 130: 18 Oct. 1634, Philip IV to Taylor; CSP, vol. 1, 150: 16 Oct. 1634, Taylor to Windebank; ibid., 236: 24 Feb. 1635, same to same; ibid., 262: 25 Apr. 1635, Hopton to same.

${ }^{66} \underline{\mathrm{CSP}}$, vol. 1, 268: 22 Apr. 1635, Olivares to Cottington.

${ }^{67}$ Bodl. Lib., Clar. Mss. 5, f. 324: 13 Aug. 1634, Hopton to Windebank.

${ }^{68}$ Taylor's instructions are in PRO, SP 80/9, ff. 34-47. The bulk of his correspondence is in: PRO, SP 80/9-10; Bodl. Lib., Clar. Mss.; HMC, Denbigh, vol. 5; and CSP, vol. 1. 
reported the news, albeit in overly optimistic terms, to the King and urged him to send a plenipotentiary as soon as possible. In response Charles sent one of his leading ministers, Thomas Howard, $2^{\text {nd }}$ Earl of Arundel and Surrey, to strike a deal with the Habsburgs. Due to the recalcitrance of the Emperor's allies, however, none was reached. Arundel left in a huff, and Taylor was ordered to remain in Vienna and continue the dialogue with the Emperor. ${ }^{69}$

Taylor's situation deteriorated with the death of Ferdinand II in 1637. For political reasons, Charles refused to acknowledge an election from which his nephew Charles Louis had been excluded and consequently would neither recognize Ferdinand III as the new emperor nor issue Taylor new credentials. ${ }^{70}$ This left Taylor in a precarious position, but he continued to receive instructions and payment from the English government and was accepted at the Imperial court as Charles's representative. From 1637 to 1639, Taylor’s negotiations with the Habsburgs progressed in fits and starts. His discussions with them focused on their proposal to hold a conference in Brussels between the parties with a vested interest in the Palatinate to settle the question once and for all.

During these last two years in Vienna, Windebank periodically reprimanded Taylor for "indiscretions" in his conduct of the negotiations, mainly because news had reached England that Taylor had delivered memorials - diplomatic petitions or memoranda - at the Imperial court and addressed Ferdinand III by the title of emperor. Taylor, who after all had been ordered to remain

${ }^{69} \mathrm{CSP}$, vol. 1, 662: [9] Oct. 1636, Windebank to Taylor.

${ }^{70} \mathrm{CSPV} 1636-9$, 168: 20 Mar. 1636, Correr to the Doge and Senate. Nor did the King approve of the exclusion of the Elector of Trier, whom the Emperor had under arrest (HHStA, StA Palatina, Kart. 12, Konv. 3: 9 Jan. 1637, Radolt to the King of Hungary, the future Ferdinand III). 
in Vienna to continue his negotiations with the Emperor, felt he had done nothing wrong. He had openly sent copies of the memorials in question to the King and Windebank, who did not think of recalling him from Vienna and even refused to do so at his repeated request. ${ }^{71}$ In reality the reason for Taylor's rebuke was his propensity to move forward more quickly and publicly than the King would have liked. Taylor completed negotiations with the Emperor for the Brussels conference during his final months in Vienna, and in early 1639 he was finally recalled at his own request. $^{72}$

The King attached no real blame to Taylor's conduct at the Imperial court until after his return to England in April 1639. ${ }^{73}$ By that time, he had found ample reason to distance himself from Taylor. The French, with whom Charles had been negotiating on and off since Arundel's return to England in January 1637, had discovered the plans for the Brussels conference. The King thus felt obliged to launch an investigation against Taylor to clear his royal name. To satisfy the war party and the French, he asked the Foreign Affairs Committee to call Taylor to account for promoting the Brussels conference without the commission to do so. ${ }^{74}$ Because of Taylor's reliance on the King and his lack of credibility with many royal ministers - both circumstances rooted in his Catholicism - Taylor was compelled to accept the consequences. The real cause of

${ }^{71}$ CCSP, vol. 1, 155-6: 7 Aug. 1638, Taylor to Windebank; ibid., 156: 21 Aug. 1638, same to same; ibid.: 28 Aug. 1638, same to same; Bodl. Lib., Clar. Mss. 16, f. 56: 1639, Taylor's relation.

${ }^{72}$ Bodl. Lib., Clar. Mss. 15, f. 88: 21 Jan. 1639, Windebank to Taylor.

${ }^{73}$ CCSP, vol. 1, 174: 29 Apr. 1639, Windebank to Hopton.

${ }^{74}$ PRO, SP 16/421, f. 62: 26 May 1639, Coke to Windebank; BL, Add. Mss. 64919: 23 May 1639, Coke's comments on Windebank's letter of same date. 
his disgrace, therefore, was not his undertakings with the Habsburgs, which were covertly encouraged by the Crown, but rather that their exposure embarrassed the King and prejudiced English negotiations for a treaty with France. As a Catholic and the King’s loyal supporter, Taylor became the unwitting scapegoat for his monarch's double-dealing foreign policy.

As a further sign that he did not sanction Taylor's actions, the King committed Taylor to the Tower in September 1639, where he remained for at least seven months. ${ }^{75}$ The erstwhile diplomat was miserable in his confinement. Not only had he purportedly offended his sovereign and been imprisoned under embarrassing circumstances, but he also found himself in dire financial straits because of the debts he incurred during his diplomatic service and imprisonment. Unable to earn money to support his family, Taylor repeatedly petitioned Windebank to intercede with the King for his release, if not to ease his own suffering and misery, then for the sake of his family. ${ }^{76}$

The difficulty of Taylor's financial situation was compounded by the final loss of his inheritance in late 1639. After years of service to the Crown, he still nurtured the hope of regaining his father's estate from his uncle John and was very upset to receive the news that his uncle had instead left the inheritance to a distant cousin and attempted to settle Taylor's claim

\footnotetext{
${ }^{75} \mathrm{~A}$. F. Pollard's Dictionary of National Biography article on Taylor claims that his books and papers were seized from the Inner Temple around the time of his arrest. However, as M. R. Trappes-Lomax rightly suspected, these items were not the property of our Taylor but another man of the same name (M. R. Trappes-Lomax, 45). Secretary Windebank did indeed order his secretary Robert Reade to seize the books and papers of a "Mr. Taylor of the Inner Temple, gent." shortly before our Taylor was sent to the Tower, but this is mere coincidence. These things almost surely belonged to the John Taylor who a short time later argued that the Secretaries of State had no place in the House of Lords (PRO, SP 16/429, f. 49: 26 Sept. 1639, Windebank to Reade; PRO, SP 16/446, f. 52: 25 Feb. 1640, Allan Boteler to same).

${ }^{76}$ PRO, SP 16/431, f. 52: 16 Oct. 1639, Taylor to Windebank; PRO, SP 16/433, f. 102: 25 Nov. 1639,
} 
with a disappointing $£ 50 .{ }^{77}$ His uncle, to be fair, may have thought it wiser to pass it on to a Protestant member of the family rather than to his imprisoned Catholic nephew. Locked away in the Tower, there was little Taylor could do. He lamented desperately to Windebank: "I know not now by what means possibly to help or relieve myself, for amongst other great crosses having lost my uncle and not only the hope which I had in him, but [I] have been hardly dealt withal and wronged in my father's estate." ${ }^{78}$ Regardless of the actual mechanics of his dispossession, the outcome remains the same - Taylor felt cheated of his inheritance and his father's legacy in Bickerton was lost. ${ }^{79}$

These repeated misfortunes took their toll on Taylor. His wife Jane petitioned the King, pleading for her husband's liberty. According to her account, Taylor was so melancholy that she feared for his life, the loss of which would result in the "utter ruin" of herself and her children. Windebank, who had helped Taylor in the past and felt guilty about his fate, advised the King to

same to same; PRO, SP 16/448, f. 112: 21 Mar. 1640, same to same.

77 Uncle John was still residing in Bickerton and a relatively wealthy man when he made out his will in October 1639, leaving the great bulk of the estate to Matthias Taylor (PRO, Probate Registers 11, vol. 182, ff. 206-7; BIHR, Original Wills, Dec. 1639).

${ }^{78}$ PRO, SP 16/433, f. 102: 25 Nov. 1639, Taylor to Windebank.

${ }^{79}$ The parish registers to the end of the seventeenth century provide no further clues about descendants of the Taylors of Bickerton Hall. With the death of Henry Clifford, $5^{\text {th }}$ Earl of Cumberland, in 1643, the earldom of Cumberland became extinct and the Clifford inheritance passed to his cousin Anne, Countess of Dorset and Pembroke. Since the Taylors' fortunes were linked so closely to those of their employers, if any family members were still in their service, they probably sought employment elsewhere. It is telling that the Taylors are not mentioned in the $5^{\text {th }}$ Earl's 1642 will (printed in J. W. Clay, 'The Clifford Family,' Yorkshire Archaeological Journal 18 [1905]: 397-9). 
release him in late $1640 .{ }^{80}$ Probably sometime before the outbreak of the English Civil War, Taylor was finally discharged from the Tower.

Despite the thankless treatment he received at the King's hands, like many gentlemen with Catholic sympathies, Taylor remained a staunch royalist. ${ }^{81}$ In fact, he eventually returned to Vienna, where his brother Francis held the post of chaplain to the Emperor Ferdinand III, to serve the King's exiled son Charles II as a diplomatic agent. ${ }^{82}$ Taylor's luck, unfortunately, did not drastically improve. His relationship with Sir Edward Hyde, Charles’s leading minister, was complicated and difficult. Hyde made no secret of his disdain for Taylor in his correspondence with his friend Sir Edward Nicholas, though it is apparent that in the beginning neither royal councilor was acquainted with or knew much about Taylor. Hyde’s low opinion of Taylor is due at least in part to his Catholicism, but in spite of this, in 1652 Hyde seriously considered sending Taylor to promote Charles II's cause at the Imperial court in Vienna and the upcoming Diet in Regensburg. ${ }^{83}$

As distasteful as it was to Hyde, Taylor's confessional allegiance was once again one of the main reasons his services were valuable. Hyde explained Taylor's effectiveness in dealing with Catholic rulers in a back-handed manner to one of his fellow Protestants: "Mr. Taylor's

\footnotetext{
${ }^{80}$ PRO, SP 16/470, ff. 164-5: [Oct?] 1640, Windebank’s cover letter to Jane Taylor’s petition.

${ }^{81}$ In Taylor's native Yorkshire, there was a significant correlation between royalism and gentry Catholicism. One historian estimates more than one-third of Yorkshire royalist families were Catholic (Cliffe, 345).

${ }^{82}$ HKA, HZAB 87 (1641); HKA, HZAB 97 (1651), f. 204.

${ }^{83} \underline{\mathrm{CSP}}$, vol. 3, 96: 13 Sept. 1652, Hyde to Nicholas. Hyde had asked for Nicholas's advice about employing Taylor, but Nicholas confused the diplomat with his brother Francis Taylor when he replied.
} 
credit may be great with Catholic princes, but his temper is not so proper to deal with those of our religion. In intercourse with Catholic princes, the style current in their courts must be used, seasonably and secretly, in mentioning the Pope." ${ }^{14}$ Ultimately, Hyde and Charles decided that Taylor's loyalty, experience, and good reputation with German Catholic rulers would make him an effective tool in their plans to muster foreign support for the Stuart cause. ${ }^{85}$ In September 1652, Taylor was accredited as resident agent to Ferdinand III and the electors of Cologne and Mainz. ${ }^{86}$

Taylor's final mission at the Imperial court was fraught with difficulties, not least because of his strained relationship with Hyde. Shortly after his appointment, they fell out over what Hyde perceived as Taylor's blatant promotion of a friend for diplomatic employment. ${ }^{87}$ Taylor was so disgusted by the whole affair that for a time he dropped all correspondence with Hyde.

${ }^{84} \mathrm{CCSP}$, vol. 2, 174: 7 Feb. 1653, Hyde to William Curtius.

${ }^{85}$ It is unclear exactly when Taylor resumed his diplomatic duties in Vienna. The earliest he can be pinpointed there is 1651. No evidence has been found to indicate that Taylor was accredited then; however, Hyde was in contact with Taylor in Vienna in June 1652, before the latter was formally accredited to the Imperial court (CCSP, vol. 2, 138: 22 June 1652, Hyde to Taylor). At this time, the Emperor considered Taylor to be the English resident agent and was defraying his expenses (HKA, HZAB 97 [1651], ff. 334, 472).

${ }^{86}$ Nicholas, vol. 1, 307-8: 5 Sept. 1652, Nicholas to Hyde; CCSP, vol. 2, 148: 6 Sept. 1652, Charles II to Ferdinand III; ibid., 149: 13 Sept. 1652, same to the electors of Cologne and Mainz. For Taylor's credentials and Hyde's side of their correspondence see Bodleian Library, Clarendon Manuscripts, and Calendar of Clarendon State Papers, vol. 2. For Taylor's letters to Prince Rupert, see British Library, Additional Manuscripts 18827, ff. 15-6, and for his memorials to the Emperor, see Haus-, Hof- und Staatsarchiv (Vienna), Staatenabteilung England, Kart. 1. The Emperor continued to defray Taylor's costs by 600 florins ( 400 thalers, or £82) for a year when he was accredited as resident agent (HKA, HZAB 99 [1653], f. 378; HKA, HZAB 100 [1654], f. 394; HKA, HZAB 101 [1655], f. 327).

${ }^{87}$ Hyde wrote Taylor a letter of rebuke and was incensed even further by his purported indiscretion in showing his friend, Sir John Henderson, the letter. Taylor claimed that Henderson inadvertently spied the letter and that he was in any case inebriated when he saw it (CCSP, vol. 2, 214: 13 June 1653, Hyde to B. 
Hyde, equally disgusted, wrote to Nicholas in November that "Taylor is the most absolute fool I ever heard of." ${ }^{88}$ While complaining acidly of Taylor's indiscretion and his long silences, Hyde still recognized the value of his loyal service. He wrote to Henry Wilmot, Lord Rochester, the following spring that "[Taylor has] much affection, zeal and integrity to the cause, ... [this] is recompense for many infirmities, which it may be he can no more mend, than he can the color of his eyes or hair." 89

Rochester had the chance to form his own opinion about Taylor, because in his role as ambassador to the Emperor, German princes, and Imperial Diet, he worked with Taylor to convince them to support Charles morally and financially. ${ }^{90}$ Taylor met Rochester as instructed in Regensburg, where the Diet convened in 1653 and 1654, but he delayed presenting his credentials, perhaps because of his feud with Hyde and Charles's failure to provide for his expenses. ${ }^{91}$ Eventually Taylor did present them, and with the aid of the elector of Mainz, he and the other English representatives succeeded in securing promises of financial assistance for

Belling, Secretary to Rochester.

${ }^{88}$ CSP, vol. 3, 121: 30 Nov. 1652, Hyde to Nicholas.

${ }^{89}$ Bodl. Lib., Clar. Mss. 45, f. 192: 28 Mar. 1653, Hyde to Rochester.

${ }^{90}$ CCSP, vol. 2, 162: 21 Dec. 1652, Rochester's commission as envoy to the German princes and Diet; ibid., vol. 2, 163: 21 Dec. 1652, Rochester to Ferdinand III; ibid., 166: [Dec.] 1652, Instructions for Rochester.

${ }^{91}$ CCSP, vol. 2, 158: 30 Nov. 1652, Hyde to Taylor; ibid., 164: 24 Dec. 1652, Charles II to same; ibid., 169: 4 Jan. 1653, Hyde to same; ibid., 174: 7 Feb. 1653, same to same. 
Charles - four subsidies (Römermonate) voted by the Diet plus a donation of 100,000 thalers from the Emperor. ${ }^{92}$

Actual receipt of this contribution, however, was dependent on the collection of the promised sums from German princes in the various Imperial circles (Reichskreise), or districts. This unenviable chore was divided among Charles's agents in Germany, and Taylor was assigned the Austrian and Bavarian circles. ${ }^{93}$ Taylor apparently had doubts that the German princes would pay and thought the Pope would more willingly aid his master, for he suggested to Hyde that he instead go to Rome to convince Innocent X to support Charles's cause. Hyde, however, disagreed, remarking acerbically: "[I] cannot believe that when the Emperor sent his Great Seal for the payment of 100,000 rix-dollars to the King, he intended that he should have nothing for it but the wax." ${ }^{94}$ He ordered Taylor to remain in Vienna lest the Emperor believe himself absolved from his promise. ${ }^{95}$ Taylor therefore continued in his discouraging task. In December 1654, six months after his departure from Regensburg, he wrote to Prince Rupert, the brother of the

${ }^{92}$ CCSP, vol. 2, 341: 24 Apr. 1654, Hyde to Richard Clement (alias of Hyde's correspondent at Rome); ibid., 349: 5 May 1654, Official notification for Rochester; ibid., 354: 18 May 1654, Ferdinand III to Rochester.

${ }^{93}$ Thurloe, vol. 2, 469: 28 July 1654, Henderson to Richard Bradshaw, English resident at Hamburg; CCSP, vol. 2, 441: [1654], Papers relating to the German Diet. These agents - Rochester, Colonel William Gunn, Sir Henry de Vic, William Curtius, and Taylor - were each assigned a collection quota in particular circles.

${ }^{94}$ CCSP, vol. 2, 381: 8 July 1654, Hyde to Taylor. Neither the Emperor nor even princes such as the Elector Palatine or the Landgrave of Hesse-Kassel paid their share. Unfortunately for Charles, the sum he received amounted to less than £10,000, and most of this was expended on Rochester's mission (CSP, vol. 2, 349-50).

${ }^{95} \mathrm{Hyde}$ also pointed out that if Charles undertook negotiations with Rome they would have to be conducted secretly, and certainly not by a known English agent like Taylor (CCSP, vol. 2, 381: 8 July 1654, Hyde to Taylor). 
now-restored Prince Palatine: "As for our business, I get nothing (as yet) but empty promises for the King being put on the Romer months [Römermonate]. Your Highness will know the uncertainty of them, especially as there are such factions amongst the German princes." 96 Although Taylor's final mission at the Imperial court was challenging and his rewards few, he carried out his diplomatic duties, the last of his career, up until his death in late $1655 .{ }^{97}$

Examining the life and career of individual Catholics like John Taylor refines our understanding of the English Catholic experience under the early Stuart monarchs. In particular, Taylor's case provides insight into the local Catholic gentry community in Yorkshire and the role of Catholics in the Caroline diplomatic service. Catholicism was strong among the Yorkshire and especially the West Yorkshire gentry, and, up until the death of Taylor's father, his family members were able to lead relatively normal lives for people of their station. Although they were by no means exempt from recusancy penalties, it is clear that the royal and ecclesiastical authorities did not apply them to the fullest extent of the law, corresponding with the commonly accepted view that the penal laws against Catholics were prudential and often laxly enforced in this period. This

${ }^{96}$ BL, Add. Mss. 18827, f. 15: 16 Dec. 1654, Taylor to Prince Rupert.

${ }^{97}$ In October or more likely November (John Thurloe, A Collection of the State Papers of John Thurloe...Containing Authentic Memorials of the English Affairs from the Year 1638 to the Restoration of King Charles II., ed. Thomas Birch [London: Printed for the Executor of F. Gyles, 1742], vol. 4, 103: 2 Nov. 1655, [H. Manning] to [Thurloe]; ibid., 169: 17 Nov. 1655, same to same). Hyde sent Prince Rupert to negotiate with the Emperor in Taylor's place, and Francis Taylor continued to correspond with the English court-in-exile (Thurloe, vol. 4, 169: 17 Nov. 1655, [Manning] to [Thurloe]; BL, Egerton 2536, f. 80: 12 Apr. 1656, Francis Taylor to Nicholas). 
does not mean that the Taylors were not affected by the consequences of their Catholicism. They certainly were, with the ultimate loss of Taylor's inheritance being the most obvious example.

Taylor’s story also demonstrates that Charles I had no qualms about taking Catholics into his service and entrusting them with negotiations of a sensitive nature. Taylor's involvement in the King's secret Habsburg foreign policy was in fact due in large part to his vulnerable financial, religious, and political position, which made him an easy scapegoat should the need for one arise. In the end, however, the King's underhanded tactics blew up in his face. While he had Taylor thrown into the Tower for openly dealing with the Emperor, this was not enough to conceal the nature of his negotiations with the Catholic Habsburgs. The exposure of Charles's secret foreign policy had momentous consequences, for it contributed to the hardening of Protestant opinion against him that manifested itself in the Civil War. 


\section{Abbreviations}

Add. Mss.

AVCB

b.

bf.

BIHR

BL

Bodl. Lib.

CCSP

Clar. Mss.

CRS

$\underline{\mathrm{CSP}}$

$\underline{\text { CSPD }}$

CSPV

d.

$\underline{\text { Denbigh }}$

HHStA

HKA

HMC

HMSO

HZAB

PRO

$\underline{\mathrm{RH}}$

$\underline{\text { Salisbury (Cecil) }}$

SP 16

SP 77

SP 80

StA

SP 94

Westm.

Yorks.
Additional Manuscripts

Archdiocese of York, Archepiscopal Visitation Court Books

born

before

Borthwick Institute of Historical Research, University of York

British Library

Bodleian Library, University of Oxford

Calendar of the Clarendon State Papers Preserved in the Bodleian Library

(Oxford: Clarendon Press, 1869-1970)

Clarendon Manuscripts

Catholic Record Society

Clarendon State Papers (Edward Hyde, Earl of Clarendon, $\underline{\text { State Papers }}$

Collected by Edward, Earl of Clarendon, Commencing from the Year

1621 , containing the materials from which his History of the great

rebellion was composed, and the authorities on which the truth of his

relation is founded [Oxford: Clarendon Printing-House, 1767-86])

Calendar of State Papers, Domestic Series, of the Reign of Charles I, 1625-[1649] (London: HMSO, 1858-97; reprint, Nendeln, Liechtenstein:

Kraus Reprint, 1967)

Calendar of State Papers and Manuscripts Relating to English Affairs

Existing in the Archives and Collections of Venice and Other Libraries in

Northern Italy (London: HMSO, 1864-1947; reprint, Nendeln,

Liechtenstein: Kraus Reprint, 1970)

died

Report on the Manuscripts of the Earl of Denbigh

Haus-, Hof- und Staatsarchiv, Vienna

Hofkammerarchiv, Vienna

Historical Manuscripts Commission, Reports

His/Her Majesty’s Stationery Office

Hofzahlamtsbücher

Public Record Office

Recusant History

Calendar of the Manuscripts of the Marquess of Salisbury (Cecil Mss.)

(London: HMSO, 1883-1976)

State Papers Domestic, Charles I

State Papers Foreign, Flanders

State Papers Foreign, German Empire and Hungary

Staatenabteilung

State Papers Foreign, Spain

Westmorland

Yorkshire 